\title{
What mineral and vitamin levels to recommend in swine diets?
}

\begin{abstract}
Didier Gaudré ${ }^{1}$, Nathalie Quiniou ${ }^{1}$
${ }^{1}$ IFIP institut du porc, la Motte au Vicomte, B.P. 35104, 35561 Le Rheu Cedex (France).

ABSTRACT -Minerals, including trace-elements, and vitamins are currently introduced into the pig diet in order to obtain suitable performances for the modern pig genotype bred in confinement. Most of the mineral and vitamin contents of cereals and usual protein compounds are characterized by their poor and variable availability. Supplemental diets are then usually needed. This paper, based on literature data, reviews the pig requirement for minerals and vitamins in order to ensure economic and profitable performance. Recent research has focused on phosphorus due to environmental considerations. The widespread use of microbial phytase has decreased the need for inorganic phosphates. Cereals are particularly deficient in calcium and sodium, consequently limestone and salt are necessary to meet the pig need for these minerals. Zinc and copper are recognized as growth promoting agents but their use at high levels is detrimental to the environment. The pig diets usually contain supplemental contents of iron, manganese, cobalt, iodine and selenium. The need for these elements in pig diets is described individually. Vitamin $\mathrm{E}$ and choline represent the most expensive vitamins added. Choline is then usually not incorporated into the pig fattening diet taking into account the choline contents of the raw materials, while vitamin E is included at a lower level than those which improve the meat quality. Our recent research has dealt with increased levels of vitamins added in combination, calculating higher requirement of the modern pig genotype. Fewer improvements have been obtained in this way, suggesting that recommendations proposed by INRA in 1984 are mainly justified.
\end{abstract}

Key Words: environment, enzymes, feeding, meat quality, modern genotype, nutritional requirements

\section{Que níveis de vitamina e mineral são recomendados em rações de suínos?}

RESUMO - Minerais, inclusive elementos traços, e vitaminas são atualmente adicionados nas rações de suínos objetivando obter performance adequada para genótipos modernos criados em confinamento. A maioria do conteúdo de mineral e vitamina dos cereais e compostos protéicos é caracterizada por sua baixa e variável disponibilidade. Dietas suplementares são então geralmente necessárias. Este artigo, baseado em dados de literatura, revê a exigência do suíno para minerais e vitaminas objetivando assegurar desempenho econômico e rentável. Recente pesquisa tem focado no fósforo devido às considerações ambientais. A propagação do uso de fitase microbial reduziu a necessidade de fosfato inorgânico. Cereais são particularmente deficientes em cálcio e sódio, consequentemente calcário e sal são necessários para atender a necessidade do suíno para estes minerais. Zinco e cobre são reconhecidos como agentes promotores de crescimento, mas sua utilização em elevados níveis são prejudiciais ao meio-ambiente. As rações de suínos geralmente contêm quantidades suplementares de ferro, manganês, cobalto, iodo e selênio. A necessidade para estes elementos nas rações de suínos é descrita individualmente. A vitamina $\mathrm{E}$ e a colina são as vitaminas mais caras a serem adicionadas. Consequentemente, a Colina não é incorporada na ração de suínos em terminação, levando-se em conta o conteúdo das matérias-primas, enquanto que a vitamina E é incluída em nível mais baixo do que aqueles que melhoram a qualidade da carne. Nossa pesquisa recente lidou com níveis elevados de vitaminas adicionadas em misturas, calculando exigências mais elevadas dos genótipos suínos modernos. Poucos avanços foram obtidos dessa maneira, sugerindo que as recomendações proposta pelo INRA em 1984 são até hoje justificadas.

Palavras-chave: alimentação, enzimas, exigências nutricionais, genótipo moderno, meio ambiente, qualidade de carne

\section{Introduction}

Minerals, including trace-minerals, and vitamins are essential nutrients for pigs. They are usually incorporated into the feed, because common feedstuffs do not have high enough concentration levels in these nutrients, when compared to the needs of the conventional breeding pig. The poor and variable availability of minerals and vitamins from raw materials also support this need. Incorporation rates of added minerals and vitamins represent less than $3 \%$ of the feed. Currently, the cost of these ingredients is mainly incurred by phosphates and supplemental vitamins, the prices of which tend to vary greatly especially in recent times. 
In practice, vitamins and trace minerals are usually put together into the feed and represent on average, 0.10, 0.15 and $0.30 \%$ of the growing-fattening, sow and piglet feeds, respectively. Macro minerals are introduced separately or could be added to the vitamin and trace mineral pre-mix, in the case of home mixer ( $25 \%$ of the pig feed production in France). A trend has been observed over recent years, especially in feed manufacture, to decrease the inclusion level of the vitamin and trace element pre-mix (from 1.0 in the early 90 's to less than $0.3 \%$ nowadays), in order to reduce the total feed cost. Precautions must be taken to preserve the quality of the feed mixing. This topic must be kept in mind when dealing with mineral and vitamin supplementations.

The aim of the first part of this paper is to review the pig's requirements for macro and trace minerals. Emphasis will be given on minerals with special importance on the environment and/or their cost. The second part deals with pig requirements for vitamins and special attention will be paid on recommended levels to ensure economic performances. It should be pointed out that the purpose of this article is not to describe the metabolic function of each vitamin as this is covered in other research.

\section{Material and Methods}

\section{Minerals and trace elements}

Pig diets are usually supplemented with limestone, phosphates and salt to meet calcium $(\mathrm{Ca})$, phosphorus $(\mathrm{P})$ and sodium (Na) needs. Table 1 illustrates the deficiencies in $\mathrm{Ca}$ and $\mathrm{Na}$ of cereals and soybean meal compared to the pig's requirements. Phosphorus is present at higher levels in current raw materials, but at a level of about 60 to 75 percent, in the form of phytate, which is poorly available to the pig. Therefore, inorganic phosphates are added. Since the earlier 90's, microbial phytase has been incorporated into the feed, to improve the availability of $\mathrm{P}$ from phytate, through the separation of $\mathrm{P}$ from phytate, making it available for intestinal absorption. Recently, the use of such an additive has been generalized and amplified, due to the sharp increase in the price of inorganic phosphates.

Table 1 - Ca, P and Na contents of several raw materials (INRAAFZ, 2004)

\begin{tabular}{lccc}
\hline$g / k g$ & $\mathrm{Ca}$ & $\mathrm{P}$ & $\mathrm{Na}$ \\
\hline Wheat & 0.7 & 3.2 & 0.1 \\
Corn & 0.4 & 2.6 & 0.04 \\
Wheat bran & 1.4 & 9.9 & 0.1 \\
Soybean meal & 3.4 & 6.2 & 0.3 \\
Fish meal & 38.5 & 25.2 & 11.3 \\
\hline
\end{tabular}

Several trace minerals are commonly added to the pig diet to ensure that the pig requirements for iron, copper, manganese, zinc, iodine, cobalt and selenium are met. Raw materials contain insufficient amounts of these nutrients, especially zinc, iodine and selenium (table 2). Furthermore, their availabilities are low and often unknown. Hence, modern pig breeding conditions tend to impose such supplementation in the form of inorganic salts. However, decision makers must be aware that interaction between minerals could lead to a deficiency in one mineral due to the excessive level of another (Perez, 1978): antagonism between copper and iron, copper and zinc, iodine and iron, calcium and copper and calcium and zinc are generally cited.

The content of other minerals i.e. magnesium, potassium, sulphur, chlorine, chromium or molybdenum are much higher in raw materials, compared to the requirements of the pig, specific supplementation is rare.

The environmental risk represented by the accumulation of minerals in the laboured soils has been pointed out over the last few decades, especially in countries where there is a high concentration of animal production. Hence, many studies have focused on the way to reduce the pig excretion of $\mathrm{P}$, copper and zinc. At the same time, national or European regulations have been adopted to limit the dietary incorporation of inorganic sources of these minerals. The trend is not over because mineral content in the plant and exported harvest is lower than the level in the liquid manure. Additionally, treatment costs of the slurry are detrimental to the pig industry development.

Macro minerals

\section{Calcium and phosphorus}

Calcium and $\mathrm{P}$ are essential to the development and constitution of the skeletal system. In the feed, $\mathrm{Ca}$ is essentially provided from limestone (on average $38 \%$ ). Inorganic phosphates contain high levels of $\mathrm{Ca}$ and $\mathrm{P}$ (on average 24.5 and $17.5 \%$ of $\mathrm{Ca}$ and $\mathrm{P}$ for the bi-calcium phosphate). Fishmeal, whey products and meat meal contain high levels of available $\mathrm{Ca}$ and $\mathrm{P}$, but their use is limited or even forbidden in western European countries. The $\mathrm{Ca}$ and P requirement of the pig is estimated by the factorial method which takes into account the needs for maintenance and production during growth, gestation or lactation periods. According to the factorial approach, the needs during growth are calculated to optimize the skeletal mineralisation (INRA, 1984). A coefficient of net intestinal absorption is then applied to the total need, in order to determine the daily requirement of the pig. This method leads to a Ca requirement of about 7 to $11 \mathrm{~g}$ per $\mathrm{kg}$ of bodyweight gain, considering 
Table 2 - Iron, zinc, manganese, copper, iodine, cobalt and selenium contents of several raw materials (INRA-AFZ, 2004)

\begin{tabular}{lccccccc}
\hline $\mathrm{mg} / \mathrm{kg}$ & Iron & Zinc & Manganese & Copper & Iodine & Cobalt & Selenium \\
\hline Wheat & 47 & 27 & 34 & 5 & 0.06 & 0.02 & 0.12 \\
Corn & 32 & 19 & 8 & 2 & 0.09 & 0.05 & 0.10 \\
Wheat bran & 143 & 74 & 112 & 17 & 0.08 & 0.09 & 0.47 \\
Soybean meal & 283 & 47 & 38 & 18 & 0.15 & 0.26 & 0.20 \\
Fish meal & 351 & 85 & 13 & 7 & 2.00 & 0.09 & 0.40 \\
\hline
\end{tabular}

a coefficient of net absorption near to $50 \%$ (INRA, 1984). In the case of $\mathrm{P}$, this coefficient is much more variable and depends on the raw materials. Several studies have been conducted over recent decades to estimate $\mathrm{P}$ digestibility for the principal components of the pig diet. According to INRA-AFZ (2004), P digestibility coefficients average to 28 and $32 \%$ for corn and soybean meal respectively, which lead to the digestible $P$ contents of 0.7 and $2.0 \mathrm{~g} / \mathrm{kg}$. In the case of inorganic sources the digestible coefficients of $P$ are 69 and $83 \%$ for the bi and mono-calcium phosphates respectively. A vegetable phytase is naturally present in straw cereals that theoretically improves the $\mathrm{P}$ digestibility from 1.0 to $1.4 \mathrm{~g} / \mathrm{kg}$ of wheat and 1.1 to $1.4 \mathrm{~g} / \mathrm{kg}$ of barley. Due to the lack of stability of the vegetable phytase in pellets and insufficient knowledge of its activity and ways to predict its content in raw materials, feed manufacturers usually ignore the contribution of this phytase. Focus is then made on microbial phytases, the activity profile of which has been defined. Table 3 presents those of 3phytase provided from Aspergillus Niger (BASF AG, Ludwigshafen, Germany). It must be highlighted that the $\mathrm{P}$ digestible equivalency due to the use of $100 \mathrm{UI} / \mathrm{kg}$ feed of phytase, decreases with increasing amounts of phytase. In other words, $1000 \mathrm{UI} / \mathrm{kg}$ of phytase are equivalent to $0.95 \mathrm{~g} /$ $\mathrm{kg}$ of digestible $\mathrm{P}$, when $500 \mathrm{UI} / \mathrm{kg}$ represent $0.75 \mathrm{~g} / \mathrm{kg}$. Therefore, it is suggested to define several "microbial phytases" in the feedstuffs database used for diet formulation, i.e phytases with decreasing activity and/or digestible P equivalency (Gaudré et al., 2008).

The digestible $\mathrm{P}$ requirement of the growing-fattening pig was estimated by Castaing et al. (2003). Based on 17 experiments, they concluded that the optimal growth performance is obtained with 2.5 and $2.0 \mathrm{~g} / \mathrm{kg}$ feed during the growing (25-65 kg bodyweight) and fattening $(65-115 \mathrm{~kg})$ periods respectively. Such levels are in agreement with the estimated values obtained from the factorial approach. The digestible $\mathrm{P}$ requirement is estimated to be 3.5 to $4.0 \mathrm{~g} / \mathrm{kg}$ for the weaned piglet and the lactating sow, and $2.7 \mathrm{~g} / \mathrm{kg}$ for the gestating sow.

The metabolisms of $\mathrm{Ca}$ and $\mathrm{P}$ are closely linked, so it was standard to take into account the $\mathrm{Ca} / \mathrm{P}$ ratio when
Table 3 - Digestible P equivalencies of the 3-phytase produced by Aspergillus Niger from 0 to $1000 \mathrm{FTU} / \mathrm{kg}$ feed (Jondreville, 2004)

\begin{tabular}{lc}
\hline $\mathrm{g} / \mathrm{kg}$ & Digestible P/100 FTU \\
\hline 0 to $250 \mathrm{FTU} / \mathrm{kg}$ & 0.196 \\
250 to $500 \mathrm{FTU} / \mathrm{kg}$ & 0.104 \\
500 to $750 \mathrm{FTU} / \mathrm{kg}$ & 0.052 \\
750 to $1000 \mathrm{FTU} / \mathrm{kg}$ & 0.028 \\
\hline
\end{tabular}

formulating the diet. Instead of the $\mathrm{Ca} /$ total $\mathrm{P}$ ratio, the use of digestible $\mathrm{P}$ now involves referring to the $\mathrm{Ca}$ /digestible $P$ ratio. According to Jongbloed et al. (1999) this ratio should range between 2.7 and $3.2 \mathrm{~g} / \mathrm{g}$ for piglets and growing pigs. An excess of $\mathrm{Ca}$ is particularly detrimental to the phytase activity, making a Ca-phytate combination that is inaccessible to the enzyme, and thus reducing the $\mathrm{P}$ digestible equivalency per unit of phytase added.

\section{Sodium}

Pig feeds are currently supplemented with 3 to $5 \mathrm{~kg}$ / ton of sodium chloride ( $38 \% \mathrm{Na}$ ) to meet the pig's requirement of $1.5 \mathrm{~g} \mathrm{Na}$ per $\mathrm{kg}$ of dry matter feed (INRA, 1984). Despite the fact that the recommendations of Jongbloed et al. (1999) are lower (1.0 g/ $\mathrm{kg}$ feed), it must be emphasised that the $\mathrm{Na}$ deficiency led to a loss of appetite. On the other hand, sodium chloride is toxic above $20 \mathrm{~kg} / \mathrm{ton}$, especially when water supply is restricted (Perez, 1978). The amounts of $\mathrm{Na}$, potassium $(\mathrm{K})$ and chlorine $(\mathrm{Cl})$ are usually taken into account together in the dietary electrolyte balance (dEB). The $\mathrm{dEB}$ is calculated as $\mathrm{Na}+\mathrm{K}-\mathrm{Cl}$ and expressed as $\mathrm{mEq} /$ $\mathrm{kg}$ feed. In this way, the $\mathrm{dEB}$ decreases when the diet tends to be acidic. The reduction of total protein contents of the feed leads to a decrease of $\mathrm{K}$ amounts. As a consequence, the dEB is reduced. This reduction is even worse when lysine content is kept at the same level through synthetic sources in such diets. Based on a literature review, Quiniou (2002) indicated that the $\mathrm{dEB}$ must be kept between 100 and 275, and 175 and $300 \mathrm{mEq} / \mathrm{kg}$ for the weaned piglet and the growing-fattening pigs respectively. Furthermore, a low dEB diet is estimated to induce skeletal demineralisation of the sow (Dourmad \& 
Meschy, 1998). Such a risk sometimes leads to the use of sodium bicarbonate in order to increase the dEB.

\section{Trace minerals}

Under most housing conditions, pigs do not have access to soil or forage. As a consequence, their needs for mineral supplementation may have increased with the generalization of confinement (NRC,1998). With the exception of iodine (I) for the thyroxin, and iron $(\mathrm{Fe})$ for the haemoglobin, trace minerals are not the constituent of tissue, unlike macro-minerals, but play a catalytic function (Perez, 1978). The role of trace elements in several deficiency symptoms was summarized by Perez (1978, Table 4). When estimating the pig's requirements, the occurrence of interactions between trace minerals or between trace minerals and other compounds of the feed must be kept in mind. It should also be noticed that the deficiency symptoms of trace minerals are not specific. For these reasons, recommended levels generally include a safety margin (Table 5).

Iron

Iron is well known to be the constituent of haemoglobin in the red blood cells, but it is also the component of several molecules, like myoglobin in the muscle or ferritin in the liver. Intra-muscular injection of iron is common practiced to meet the needs of the suckling piglet because the sow's milk is deficient in this trace mineral. After weaning, the requirement is about $80 \mathrm{mg} / \mathrm{kg}$ and tends to decrease during the fattening period in relation to the lower relative content of blood in bodyweight gain (NRC, 1998). Although, contents and availabilities of iron from raw materials are high enough for the pig (NRC, 1998), diets are usually supplied with only $100 \mathrm{mg} / \mathrm{kg}$ of iron sulphate in order to avoid any deficiency. Zinc

Zinc is the component of many enzymes and thus plays various roles in protein, carbohydrate, lipid and nucleic metabolisms. Many feed constituents are known to increase the need, especially plant phytates and Ca (NRC, 1998). Consequently zinc sulphate or oxide $(100 \mathrm{mg} / \mathrm{kg})$ is currently added to pig diets. At pharmacological levels ( 2000 to $3000 \mathrm{mg} / \mathrm{kg}$ ), zinc oxide is fed to weaned piglets to prevent diarrhoea and promote growth. Such use is forbidden in France, Germany and the Netherlands while Spain, Denmark, England and Italy have adopted the strategy to temporarily authorize this pharmacological treatment, during the first two weeks after weaning, under veterinarian control. This practice is stigmatised as unfair competition by several feed manufacturers in France, but the adverse effect on the environment must also be pointed out. The retention of zinc by the pig is only $22 \mathrm{mg} / \mathrm{kg}$ bodyweight (Dourmad et al., 2002). Hence, almost all of the zinc ingested is excreted in the slurry (Revy et al., 2003). In this context, the maximal zinc content (zinc provided from feedstuffs and mineral supplementation) authorized in the European Union was reduced from 250 to $150 \mathrm{mg} / \mathrm{kg}$ in 2003 . The use of phytase could also reduce the level of zinc

Table 4 - Deficiency and sub-deficiency symptoms of trace minerals in the pig (Perez, 1978)

\begin{tabular}{lcccc}
\hline & Iron & Zinc & Manganese & Copper \\
\hline Appetite & $*$ & $* *$ & & Selenium \\
Performances & $*$ & $* *$ & $*$ & $*$ \\
Fertility disorders & & $*$ & $* *$ & $*$ \\
Skeletal disorders & $* *$ & $*$ & $* *$ & $*$ \\
Anaemia & & $* *$ & $*$ & $*$ \\
Skin or hair anomalies & & & $*$ & $*$ \\
Heart disorders & & & $*$ \\
Goitre & & & $*$ \\
Muscular dystrophy & & & $*$ \\
\hline
\end{tabular}

Table 5 - Supplemented trace minerals recommendations (INRA, 1984)

\begin{tabular}{lccc}
\hline $\mathrm{mg} / \mathrm{kg}$ & Piglet & Pig & Sow \\
\hline Iron & 100 & 80 & 80 \\
Zinc & 100 & 100 & 100 \\
Copper & 10 & 10 & 10 \\
Manganese & 40 & 40 & 40 \\
Iodine & 0.6 & 0.2 & 0.6 \\
Cobalt & $0.1-0.5$ & 0.1 & 0.1 \\
Selenium & 0.3 & 0.1 & 0.1 \\
\hline
\end{tabular}

supply. Gaudré et al. (2006) demonstrated that 750 UI of 3 phytase produced byAspergillus Niger, can substitute for $40 \mathrm{mg} / \mathrm{kg}$ feed of supplemented zinc.

\section{Manganese}

Manganese is essential for the development of the skeleton. It is the component of many enzymes involved in protein, lipid and carbohydrate metabolisms. A manganese deficiency in the diet of the sow could induce reproduction 
disorders (Perez, 1978). The NRC's requirement for the sow $(20 \mathrm{mg} / \mathrm{kg}$ ) is based on studies which demonstrated the decrease of piglet birth weight using $5 \mathrm{mg} / \mathrm{kg}$ instead of $20 \mathrm{mg} / \mathrm{kg}$, associated to a delayed return to oestrus after weaning (Christianson et al., 1990). Kirchgessner et al. (1981) estimated that the need for manganese is $25 \mathrm{mg} / \mathrm{kg}$ for the sow and INRA (1984) recommended $40 \mathrm{mg} / \mathrm{kg}$ to avoid any feed deficiency. The usual form of supplementation is manganese oxide.

\section{Copper}

Copper, involved in the defence of the organism against oxidative stress, is required for the synthesis of haemoglobin, and plays a role in the immune system (Jondreville et al., 2002). While the pig's requirement is less than $10 \mathrm{mg} / \mathrm{kg}$ feed (NRC, 1998), usual supplementation in piglet diets is currently near $150 \mathrm{mg} / \mathrm{kg}$, due to a growth promoting effect during this stage. The copper retention represents less than $2 \mathrm{mg} / \mathrm{kg}$ bodyweight (Jondreville et al., 2002). Therefore, almost all of the copper ingested is then excreted. Regulations on total feed content of copper were adopted in 2003, for environmental reasons. It induced a drastic change on copper supplementation during growing and fattening periods. The maximal authorized content of copper in the feed is now $25 \mathrm{mg}$ per $\mathrm{kg}$ of feed, whereas it was $100 \mathrm{mg}$ before 2003. Several veterinarians indicate an increase in gut disorders due to this change, especially at the beginning of the growing phase and in low-clean breeding conditions. It is not known if this regulation induces an increased use of antibiotics. Copper is usually supplied in the form of copper sulphate.

\section{Iodine}

The majority of iodine in swine is present in the thyroid gland as a component of the thyroxine hormone which regulates the metabolic rate (NRC, 1998). The deficiency status led to an increase of piglet stillbirths. The presence of goitrogens substances from several feedstuffs like soybean meal can increase the requirement (NRC, 1998). Cromwell et al. (1975) established that the requirement of the growing pig fed a corn soybean meal is approximately 0.09 to $0.14 \mathrm{mg} / \mathrm{kg}$. Safety margins are often used in commercial pig diets through calcium iodate or iodure salts.

\section{Cobalt}

Cobalt is a component of the cyanocobalamin (vitamin $\mathrm{B} 12)$. There is no evidence that the pig requires cobalt supplements (NRC, 1998). A production activity of cyanocobalamin occurs in the hind gut of the pig (Perez, 1978). Based on cyanocobalamin diet supplementation and pig tendency to coprophagy behaviour, it can be concluded that diet supplementation has no purpose. For these reasons, sulphate cobalt salt is sometimes omitted from the diet.

\section{Selenium}

As a component of the enzyme glutathione peroxidase, selenium helps cellular membranes to protect against perodixe damage, in association with vitamin E (NRC, 1998). Based on glutathion peroxidase activity in the plasma, Mahan et al. (1999) concluded that 0.10 and $0.05 \mathrm{mg} / \mathrm{kg}$ of added selenium are sufficient in growing and fattening periods respectively, but they didn't notice any change in performances and carcass characteristics up to $0.3 \mathrm{mg} / \mathrm{kg}$. Compared to a negative control, an improved newly born piglet survival rate is obtained with $0.15 \mathrm{mg} / \mathrm{kg}$ of added selenium in the form of sodium selenite or enriched selenium yeast (Mahan \& Peters, 2004). No additional effect is observed with $0.3 \mathrm{mg} / \mathrm{kg}$, while the organic source results in greater selenium concentration in the milk. Due to the extremely variable concentration and availability of selenium in soil, several regions of the United States must use selenium supplements to ensure animal health and productivity (Ullrey, 1992). With regard to the risk of selenium deficiency, nutritionists called for regulation in favour of the use of supplemented selenium. It was then authorized in 1974 in the U.S and the maximal authorized level increased from 0.1 to $0.3 \mathrm{mg} / \mathrm{kg}$ between 1974 and 1987 . The effect of excess dietary selenium on the environment has been pointed out. In the European Union, the maximal content of the feed must not exceed $0.5 \mathrm{mg} / \mathrm{kg}$, while only $5 \mathrm{mg} / \mathrm{kg}$ is considered to be toxic for the pig (Perez, 1978).

Vitamins

Nutrient functions and general considerations on vitamin requirement estimation

Vitamins are essential nutrients for animals. Most of them can be defined as substances that the animal is unable to synthesize, acting in low dose, and not interchangeable (Ferrando et al., 1986). Two groups of vitamins are currently distinguished based on their solubility. Vitamins A, D, E and $\mathrm{K}$ are lipid-soluble, whereas $\mathrm{B}$ vitamins are watersoluble. Vitamins D and K are involved in mineral metabolism and blood coagulation respectively. Vitamins $\mathrm{A}$ and $\mathrm{E}$ are involved in a lot of metabolism pathways, and in consequence could be implicated in overall performances. Group-B vitamins are co-enzymes required in numerous metabolisms (carbohydrates, lipids, proteins, nucleic acids).

Feedstuffs contain vitamins, but it must be underlined that their contributions are very difficult to take into account. 
The amount of vitamins in feedstuffs varies between publications. Pyridoxine (B6) exists in the form of three active compounds that complicate laboratory analyses (INRA, 1984). It could also vary between crops, harvest and variety, as it is the case for biotin $(\mathrm{H})$ from cereals (INRA, 1984). Vitamins from raw materials could exist in different molecular forms with varied activities. The L-isomer of biotin is a biologically inactive form for the pig (NRC, 1998). Vitamin $\mathrm{E}$ is present in feedstuffs in eight natural forms ( $\alpha, \beta, \gamma$ and $\delta$ tocopherols and tocotrienols), each characterized by its own vitamin $\mathrm{E}$ activity. Interactions with feed components also need to be mentioned, because they can increase or decrease the need for supplementation. The presence of methionine reduces the need for cyanocobalamin (B12), as does the presence of tryptophane for niacin (PP). Niacin in cereals is largely unavailable to young pigs (NRC, 1998). Furthermore, it must be specified that the vitamins naturally present in raw materials are unstable, especially in the case of tocopherols and tocotrienols, and also with thiamin (B1) when heat treatment is applied.

The gastro intestinal tract is colonized by numerous bacterial populations. A production activity of vitamins K, folic acid (B9), cyanocobalamin, niacin, and biotin can be observed in the large intestine. Except for vitamin K which can be directly digested, the absorption of B vitamins needs coprophagy. The generalization of slatted floors in modern breeding conditions, tends to reduce this vitamin supply.

However, the contribution from raw materials and intestinal syntheses is usually considered in the case of thiamin, riboflavin (B2), pantothenic acid (B5), niacin, biotin, choline, pyridoxine, folic acid and vitamin E provided from raw materials, and vitamins $\mathrm{K}$, folic acid, cyanocobalamin, biotin and niacin due to intestinal bacterial activity.

Investigations into vitamin needs of animals are particularly complex. Deficiency symptoms are not specific, especially for water-soluble vitamins. Synthetic diets are necessary to avoid the presence of vitamins from raw materials, and attention must be paid on interaction with intestinal synthesis, and with other nutrients that increase or decrease the need. Liver storage would interact with requirement assessments for vitamins $\mathrm{A}, \mathrm{E}$ and B12, by buffer effect. The variability of needs among individuals and evolution of needs with genetic improvement must also be emphasized; most of the determination of vitamin requirements were conducted in the 40's and 50's, with an animal model far removed from our current pig. The observed performances are considered to be, in several cases, insufficient criteria to estimate the real need. Other parameters provided from blood, bone, liver, colostrum or milk are therefore measured to complete the data. Such parameters are chosen in relation to the metabolic role of the vitamin studied. Sometimes, the levels optimising performances are lower than those optimising the parameter. In such a case, decision makers must be aware of the supplemental cost of the vitamin.

\section{Literature review}

This literature review aims to point out recent and noteworthy results that could help the reader to define diet supplemental levels of vitamins needed by the modern breeding herd.

Cure treatment of vitamins is usually practiced on the sow herd, but apparently it seems unjustified because, except for vitamin B12, liver storage of vitamin B doesn't exist. Additionally, liver storage of vitamin E is limited. Then most of the studies and recommendations focus on the daily rate and consequently, regular ingestion of vitamins.

\section{Vitamin A}

Vitamin A supplementations of $40000 \mathrm{UI} / \mathrm{kg}$ for piglets and $50000 \mathrm{UI} / \mathrm{kg}$ for pigs failed to improve feed efficiency or average daily gain. On the other hand, small amounts ( $<500 \mathrm{UI} / \mathrm{kg}$ ) are enough to optimise performances. Long term studies on sows are complicated by the high storage capacity of the liver. Due to the oxidation sensitivity of natural and in a lesser extent commercial sources of vitamin A, supplementation is usually kept at a high level, knowing that the cost of $5000 \mathrm{UI} / \mathrm{kg}$ is not expensive (approximately $0.17 € / \mathrm{T})$.

\section{Vitamins D and $K$}

The pig's ability to cope with a deficiency of vitamin D is high (Pointillart, 1980), while intestinal synthesis of vitamin $\mathrm{K}$ is able to meet the body's requirements. However, because the supplementation of vitamins D and $\mathrm{K}$ is cheap, levels are usually near $2000 \mathrm{UI} / \mathrm{kg}$ for vitamin D and between 0.5 to $1.0 \mathrm{mg} / \mathrm{kg}$ for vitamin $\mathrm{K}$.

\section{Vitamin E}

Vitamin E is the most expensive vitamin. Every $10 \mathrm{UI} / \mathrm{kg}$ costs approximately $0.35 € /$ ton. The need for vitamin $\mathrm{E}$ for the growing pig was reviewed by Ullrey (1981) on the basis of 22 publications. He recommended a level of vitamin $\mathrm{E}$ between 10 and $20 \mathrm{UI}$ per $\mathrm{kg}$ feed and even $30 \mathrm{UI} / \mathrm{kg}$ when a problem occurred in the breed. At the opposite end of the scale, $5 \mathrm{UI} / \mathrm{kg}$ appeared insufficient. Conclusions drawn by Jensen et al. (1988) were similar; 15 UI/kg are suitable, 30 UI/ 
$\mathrm{kg}$ could be used taking into account the variability of the need between pigs and including a safety margin. The effect of vitamin E on meat quality has been the subject of many studies. Unfortunately, an expensive level of vitamin $\mathrm{E}$ ( 100 to $200 \mathrm{UI} / \mathrm{kg}$ ) is needed to modify the colour of meat and/or resistance to oxidation. Antagonism between vitamins A and E was demonstrated by Ching et al. (2002) on piglets. Blood content of tocopherol was reduced from 20 to $30 \%$ when the A supplementation increased from 2200 to $13200 \mathrm{UI} / \mathrm{kg}$. This antagonism must be kept in mind even if it hasn't been confirmed on fattening pigs with $20000 \mathrm{UI} / \mathrm{kg}$ of vitamin A (Anderson et al., 1995). Vitamin E supplementation for sows has increased in France since the early 90's (approximately, 20 to 80 UI/kg), in response to the widespread use of hyper-prolific sows. Also, the simultaneous reduction of its cost might help this trend. In fact, demonstration of such a high supplementation is scarce. Mahan (1994) recommended $44 \mathrm{UI} / \mathrm{kg}$ for both gestating and lactating sows based on a slight increase of the number of piglets born alive.

\section{Thiamin}

Thiamin is abundant in cereals and soybean meal (> $4 \mathrm{mg} / \mathrm{kg}$ ). Whatever the physiological stage, experiments failed to improve performances, when more than $1 \mathrm{mg} / \mathrm{kg}$ of supplemented thiamin was added (Newcomb \& Allee, 1986; Woodworth et al., 2000, Easter et al., 1983; Lutz et al., 1999).

\section{Riboflavin}

Recent works have been conducted on riboflavin. Lutz $\&$ Stahly (1998) showed a linear increase of average daily gain, feed efficiency and body protein accretion of highlean piglets with 3.7 and $7.4 \mathrm{mg} / \mathrm{kg}$ of riboflavin added (Table 6). They determined that the riboflavin need, necessary for the protein accretion, is six times higher than that necessary for the fat deposit. In other words, riboflavin need is directly dependent on the genetic potential of the pigs. Unfortunately, no significant changes in pig fattening performances were observed (Gaudré \& Granier, 2009) with added riboflavin up to $18 \mathrm{mg} / \mathrm{kg}$ (Table 7). But it must be pointed out that in this experiment, the lowest level was 3 $\mathrm{mg} / \mathrm{kg}$ of riboflavin added, plus $1.6 \mathrm{mg} / \mathrm{kg}$ provided from feedstuffs.

\section{Pantothenic acid}

Slight improvements in performance are obtained with pantothenic acid addition. Grinstead et al. (1988) showed on piglets weaned at 11 days old, an increase in average daily gain with $120 \mathrm{mg} / \mathrm{kg}$ of pantothenic acid added and in feed efficiency with $30 \mathrm{mg} / \mathrm{kg}$. Stahly \& Lutz (2001) improved
Table 6 - Effect of added riboflavin on piglet performance (Lutz \& Stahly, 1998)

\begin{tabular}{lccc}
\hline Added riboflavin mg/kg & 0 & 3.7 & 7.4 \\
\hline ADG $(\mathrm{g} / \mathrm{d})$ & 645 & 677 & 696 \\
FCR $(\mathrm{kg} / \mathrm{kg})$ & 1.43 & 1.36 & 1.34 \\
Protein accretion $(\mathrm{g} / \mathrm{d})$ & 110 & 115 & 118 \\
\hline
\end{tabular}

Table 7 - Effect of added riboflavin on pig performance (Gaudré \& Granier, 2009)

\begin{tabular}{lcccc}
\hline Added riboflavin mg/kg & 3 & 6 & 9 & 18 \\
\hline ADG (g/d) & 938 & 961 & 946 & 927 \\
FCR (kg/kg) & 2.80 & 2.80 & 2.80 & 2.74 \\
Lean thickness (mm) & 56.0 & 57.4 & 56.7 & 57.4 \\
\hline
\end{tabular}

lean percent carcass with $30 \mathrm{mg} / \mathrm{kg}$ without any other change in fattening performances observed.

Pyridoxine

Woodworth et al. (2000) improved the average daily gain of weaned piglets from day 0 to 14 , with $3.3 \mathrm{mg}$ of pyridoxine added and $4.6 \mathrm{mg}$ provided from feedstuffs. They concluded that the requirement of the weaned piglet is nearer to $7.9 \mathrm{mg} / \mathrm{kg}$. Unfortunately, this positive effect was not observed by Newcomb \& Allee (1986) with the same supplemental level.

\section{Folic acid}

Because of the contribution by raw materials and intestinal synthesis, the need for folic acid is considered as low, with the exception of the young animal and the pregnant sow. The addition of folic acids on piglets and pigs were tested, without any positive change, by Newcomb \& Allee (1986), Easter et al. (1983) and Lutz et al. (1999). Sow prolificacy is not always increased by acid folic additions: Harper et al. (1994) with 1, 2 or $4 \mathrm{mg} / \mathrm{kg}$, Matte et al. (1992) with 5 or $15 \mathrm{mg} / \mathrm{kg}$ throughout pregnancy. This effect seems dependent on the ovulation rate (Lindemann \& Kornegay, 1989), since the latter increases with parity.

\section{Cyanocobalamin}

Simard et al. (2004) observed improvements in total piglets born and weaned with high levels of vitamin B 12 (cyanocobalamin) in the diets of pregnant sows (0.2 and $0.4 \mathrm{mg} / \mathrm{kg}$ ). The piglet hepatic storage of B12 tends to increase at the same time. It should be highlighted that this test was carried out with only 8 sows per treatment, and needs to be confirmed on a larger scale. Furthermore, the cost of 0.2 to $0.4 \mathrm{mg} / \mathrm{kg}$ of cyanocobalamin is similar to the addition of 12 to $24 \mathrm{UI} / \mathrm{kg}$ of vitamin E. The weaned piglet didn't show any increase in its performance with 
up to ten times the NRC requirement (Lindeman et al., 1995).

\section{Niacin}

Niacin supplementation is required when the content of niacin calculated from raw materials, is lower than 1.5 times the minimal need (INRA, 1984): 33, 18 and $15 \mathrm{mg} / \mathrm{kg}$ for piglet, pig and sow, respectively. This recommendation is based on the low availability of niacin from raw materials (corn especially), and the presence of natural antagonism from niacin. No effect was observed by Copelin et al. (1980) and Ivers \& Veum (1993) up to 22 and $81 \mathrm{mg} / \mathrm{kg}$ of added niacin respectively, while Real et al. (2002) demonstrated improved growth and feed efficiency performance with 13 to $55 \mathrm{mg} / \mathrm{kg}$.

\section{Biotin}

The interest of biotin supplementation for weaned piglets and growing-finishing pigs was not demonstrated (Newcomb \& Allee, 1986; Easter et al., 1983; Hamilton \& Veum, 1986; Bryant et al., 1985a). On the other hand, several studies tend to conclude that biotin supplementation needs to be added to the feed for the sow (Hamilton \& Veum, 1984; Bryant et al., 1985b,c; Lewis et al., 1991) with the exception of Watkins et al. (1991). Results indicate that 0.3 to $0.55 \mathrm{mg} / \mathrm{kg}$ could enhance sow performance (Table 8 ).

\section{Choline}

Choline is not strictly considered as a vitamin but supplementation could be efficient to complement choline provided from raw materials. The sow requirement is $2000 \mathrm{mg} / \mathrm{kg}$ taking into account each source of choline (INRA, 1984). Additionnally, NRC (1998) indicates that supplemental choline is not necessary for growingfattening pigs eating a diet rich in soybean meal. Choline is very expensive $(300 \mathrm{mg} / \mathrm{kg}$ induce $0.5 € / \mathrm{T})$ and is usually restricted to the sow and piglet feed.

\section{Effects of vitamins added in combination}

During the last few years, IFIP has carried out several studies on vitamin requirements. The approach was to estimate the effect of vitamins added in combination. In these experiments, the control treatment was considered to be represented by usual practice. The growing-fattening trial (Gaudré \& Vautier, 2006) aimed at comparing a high level of combined vitamins (Table 9), but no significant improvement was observed on breeding performances and carcass characteristics. A tendency to enhance average daily gain and feed intake of piglets weaned in low-clean conditions, was demonstrated due to a moderate increase in added vitamins (Table 10). This result is similar to those published recently with added vitamins B (Wilson et al.,

Table 8 - Effects of biotin supplementation on sow productivity

\begin{tabular}{lcc}
\hline Author & $\mathrm{mg} / \mathrm{kg}$ & Noticed improvement \\
\hline Hamilton \& Veum (1984) & 0.55 & Piglets weaned on first parity \\
Bryant et al. (1985b,c) & 0.44 & Trend on prolificacy, weaning-oestrus interval and foot lesions \\
Lewis et al. (1991) & 0.33 & Weaned/born alive \\
Watkins et al. (1991) & 0.44 & Nothing \\
\hline
\end{tabular}

Table 9 - Supplemented vitamin levels compared on growing-fattening pigs (Gaudré \& Vautier, 2006)

\begin{tabular}{|c|c|c|c|c|c|}
\hline \multirow[t]{2}{*}{ Vitamin } & \multirow[t]{2}{*}{ Unit/kg } & \multicolumn{2}{|c|}{ Growing period $(25-60 \mathrm{~kg})$} & \multicolumn{2}{|c|}{ Fattening period $(60-115 \mathrm{~kg})$} \\
\hline & & Control & Test & Control & Test \\
\hline A & UI & 6260 & 10000 & 5700 & 8000 \\
\hline D3 & UI & 1200 & 2000 & 1075 & 1500 \\
\hline $\mathrm{E}$ & UI & 9 & 60 & 8 & 50 \\
\hline K3 & $\mathrm{mg}$ & 0.26 & 3 & 0.12 & 1.5 \\
\hline B1 (Thiamin) & $\mathrm{mg}$ & 0.5 & 2 & 0.4 & 1.5 \\
\hline B2 (Riboflavin) & $\mathrm{mg}$ & 2.3 & 10 & 2 & 8 \\
\hline B5 (Pantothenic Ac.) & $\mathrm{mg}$ & 7 & 40 & 6 & 40 \\
\hline B6 (Pyridoxine) & $\mathrm{mg}$ & 0.5 & 4 & 0.4 & 3 \\
\hline B12 (Cyanocobalamin) & $\mathrm{mg}$ & 0.014 & 0.04 & 0.012 & 0.035 \\
\hline PP (Niacin) & $\mathrm{mg}$ & 11 & 30 & 10 & 30 \\
\hline Folic Ac. & $\mathrm{mg}$ & 0 & 1 & 0 & 1 \\
\hline Biotin & $\mathrm{mg}$ & 0 & 0.25 & 0 & 0.2 \\
\hline Choline & $\mathrm{mg}$ & 300 & 300 & 200 & 200 \\
\hline
\end{tabular}


1992a,b; Lindemann et al., 1995; Stalhy et al., 1995) or B and fat-soluble vitamins (Castaing et al., 2001). In a cooperative study, involving 336 sows from two herds (Quiniou \& Calvar, 2005), no improvement in productivity was noticed when using higher than recommended levels of vitamin $\mathrm{E}$, $\mathrm{K}$ and a range of $\mathrm{B}$ vitamins (Table 11). Before publication

Table 10 - Supplemented vitamin levels compared on piglets (Gaudré, 2007)

\begin{tabular}{lccc}
\hline Vitamin & Unit/kg & Control & Test \\
\hline A & UI & 8000 & 12000 \\
D3 & UI & 1500 & 2000 \\
E & UI & 20 & 60 \\
K3 & $\mathrm{mg}$ & 0.5 & 2 \\
B1 (Thiamin) & $\mathrm{mg}$ & 1 & 2 \\
B2 (Riboflavin) & $\mathrm{mg}$ & 4 & 8 \\
B5 (Pantothenic Ac.) & $\mathrm{mg}$ & 10 & 20 \\
B6 (Pyridoxine) & $\mathrm{mg}$ & 1.5 & 3 \\
B12 (Cyanocobalamin) & $\mathrm{mg}$ & 0.015 & 0.03 \\
PP (Niacin) & $\mathrm{mg}$ & 15 & 45 \\
Folic Ac. & $\mathrm{mg}$ & 0.5 & 1 \\
Biotin & $\mathrm{mg}$ & 0 & 0.1 \\
Choline & $\mathrm{mg}$ & 300 & 450 \\
\hline
\end{tabular}

Table 11 - Supplemented vitamin levels compared on sows (Quiniou \& Calvar, 2005)

\begin{tabular}{lccc}
\hline Vitamin & Unit/kg & Control & Test \\
\hline A & UI & 9600 & 9600 \\
D3 & UI & 1960 & 1960 \\
E & UI & 50 & 90 \\
K3 & $\mathrm{mg}$ & 0.5 & 1 \\
B1 (Thiamin) & $\mathrm{mg}$ & 0.6 & 1.5 \\
B2 (Riboflavin) & $\mathrm{mg}$ & 4.2 & 6 \\
B5 (Pantothenic Ac.) & $\mathrm{mg}$ & 10 & 20 \\
B6 (Pyridoxine) & $\mathrm{mg}$ & 0.6 & 2.5 \\
B12 (Cyanocobalamin) & $\mathrm{mg}$ & 0.025 & 0.025 \\
PP (Niacin) & $\mathrm{mg}$ & 17 & 35 \\
Folic Ac. & $\mathrm{mg}$ & 1.8 & 3.5 \\
Biotin & $\mathrm{mg}$ & 0.15 & 0.30 \\
Choline & $\mathrm{mg}$ & 600 & 600 \\
\hline
\end{tabular}

of these works, there was a trend in Britanny to increase feed vitamin supplementation, believing that common practice of feed manufacturers led to nutrient deficiencies in pigs. It was demonstrated that little improvement in performances could be obtained in this way.

\section{Levels of vitamins recommended by phase}

Based on review literature and our own recent investigations described above, recommendations were formulated for added vitamins (Table 12). These recommendations are partly based on those established by INRA in 1984. Bearing in mind the various sources of incertitude, intervals of variation are sometimes indicated. In some cases, recommended levels are made but they are based on a limited number of trials. Taking into considerations, the price and time-varying of vitamins, feed components, the use of safety margins, as well as newly acquired knowledge, judgements could be arrived at in favour of contribution levels different from those suggested here.

\section{Conclusions}

The inclusion of minerals, including trace elements, and vitamins in pig diets is needed to ensure optimal performance of the actual pig genotype deprived of access to soil or forage. Recent knowledge has been collected on phosphorus, zinc and copper in response to increasing awareness of detrimental effects of the excess of these minerals on the environment. As a consequence, investigations have been conducted in order to limit the total excretion of the pig, considering that the retention of phosphorus, zinc and copper is generally not affected by diet content. Partly due to a decrease in the protein in the diet and thus potassium content, attention has been paid on

Table 12 - Recommended levels for vitamins (IFIP, 2005)

\begin{tabular}{|c|c|c|c|c|c|c|c|c|}
\hline \multirow[t]{2}{*}{ Vitamin } & \multirow[t]{2}{*}{ Units/kg } & \multirow[t]{2}{*}{ Cost } & \multicolumn{2}{|c|}{ Piglet } & \multicolumn{2}{|c|}{ Pig } & \multicolumn{2}{|c|}{ Sow } \\
\hline & & & $7-12 \mathrm{~kg} \mathrm{BW}$ & $12-25 \mathrm{~kg} \mathrm{BW}$ & $25-60 \mathrm{~kg} \mathrm{BW}$ & $60-115 \mathrm{~kg} \mathrm{BW}$ & Pregnant & Lactating \\
\hline A & UI & $\$ \$$ & 10000 & 8000 & 7000 & 5000 & 5000 & 8000 \\
\hline D3 & UI & $\$$ & 2000 & 1500 & 1000 & 1000 & 2000 & 2000 \\
\hline $\mathrm{E}$ & UI & $\$ \$ \$$ & 50 & 20 & $10-15$ & $10-15$ & 45 & 45 \\
\hline K3 & $\mathrm{mg}$ & $\$$ & 1 & $0.5-1$ & 0.5 & 0.5 & 0.5 & 0.5 \\
\hline B1 (Thiamin) & $\mathrm{mg}$ & $\$$ & 1 & $0.5-1$ & $0-1$ & $0-1$ & 1 & 1 \\
\hline B2 (Riboflavin) & $\mathrm{mg}$ & $\$ \$$ & $4-8$ & $4-8^{*}$ & 3 & 2 & 3 & 3 \\
\hline B5 (Panto. ac.) & $\mathrm{mg}$ & $\$ \$$ & 10 & 10 & 8 & 7 & 8 & 8 \\
\hline PP (Niacine) & $\mathrm{mg}$ & $\$ \$$ & 15 & 15 & 10 & 7 & 10 & 10 \\
\hline B6 (Pyridoxine) & $\mathrm{mg}$ & $\$ \$$ & $0-3.6^{*}$ & $0-1$ & 0 & 0 & 1 & 0 \\
\hline B 12 (Cyanocobalamin) & $\mathrm{mg}$ & $\$ \$$ & 0.035 & 0.03 & 0.02 & 0.02 & $0.02-0.2$ & 0.02 \\
\hline Folic ac. & $\mathrm{mg}$ & $\$ \$$ & 0.5 & 0.5 & $0-0.5$ & $0-0.3$ & $0.2-15^{*}$ & $1-15^{*}$ \\
\hline Biotin & $\mathrm{mg}$ & $\$ \$ \$$ & 0.1 & $0-0.1$ & $0-0.05$ & 0 & $0.3-0.5$ & $0.3-0.5$ \\
\hline Choline & $\mathrm{mg}$ & $\$ \$ \$$ & $300-800$ & $300-800$ & $0-300$ & $0-100$ & $400-900$ & $400-900$ \\
\hline
\end{tabular}

\footnotetext{
${ }^{*}$ These levels are based on a limited number of trials.
} 
the dietary electrolyte balance taking into account respective levels of sodium, potassium and chlorine, but real proof of their reliability remains scarce. Over the last two decades, focus has been made on vitamin requirements, since most of the research conducted in the 40's and 50's, was based on an animal model far removed from our current pig. Several studies have been carried out in order to estimate if improved performance could be obtained at higher vitamin levels than current recommendations. Our recent research and literature review have been summarized in practical recommendations presented above. Safety margins could be introduced bearing in mind the actual cost of each vitamin.

\section{Literature Cited}

ANDERSON, L.E.; MYER, R.O.; BRENDEMUHL, J.H. et al. The effect of excessive dietary vitamin A on performance and vitamin $\mathrm{E}$ status in swine diets varying in dietary vitamin $\mathrm{E}$. Journal of Animal Science, v.73, p.1093-1098, 1995.

BRYANT, K.L.; KORNEGAY, E.T.; KNIGHT, J.W. et al. Supplemental biotin for swine. I. Influence on feedlot performance, plasma biotin, and toe lesions in developing gilts. Journal of Animal Science, v.60, n.1, p.136-144, 1985a.

BRYANT, K.L.; KORNEGAY, E.T.; KNIGHT, J.W. et al. Supplemental biotin for swine. II. Influence of supplementation to corn and wheat based diets on reproductive performance and various biochemical criteria of sows during four parities. Journal of Animal Science, v.60, n.1, p.145-153, 1985b.

BRYANT, K.L.; KORNEGAY, E.T.; KNIGHT, J.W.; et al. Supplemental biotin for swine. III. Influence of supplementation to corn and wheat based diets on the incidence and severity of toe lesions, hair and skin characteristics and structural soundness of sows housed in confinement during four parities. Journal of Animal Science, v.60, n.1, p.154-162, 1985c.

CASTAING, J.; CAMBEILH, D.; HAMELIN, C. Incidence des apports en vitamines sur les performances des porcelets en deuxième âge. Journées de la Recherche Porcine, v.33, p.227-232, 2001.

CASTAING, J.; PABOEUF, F.; SKIBA, F. et al. Estimation du besoin en phosphore digestible apparent du porc charcutier : synthèse d'essais zootechniques effectués au cours des dix dernières années. Journées de la Recherche Porcine, v.35, p. 47-54, 2003.

CHING, S.; MAHAN, D.C.; WISEMAN T.G. et al. Evaluating the antioxidant status of weanling pigs fed dietary vitamins A and E. Journal of Animal Science, v.80, p. 2396-2401, 2002.

CHRISTIANSON, S.L.; PEO, E.R.; LEWIS, A.J. et al. Influence of dietary manganese levels on reproduction, serum cholesterol and milk manganese concentration of sows. Journal of Animal Science, v.68, Suppl.1, Abstracts, p.368, 1990.

COPELIN, J.L.; MONEGUE, H.J.; COMBS, G.E. Niacine levels in growing-finishing swine diets. Journal of Animal Science, abstracts, p.190, 1980 .

CROMWELL, G.L.; SIHOMBING, D.T.H.; HAYS, V.W. Effects of iodine level on performance and thyroid traits of growing pigs. Journal of Animal Science, v.41, n.3, p.813-818, 1975

DOURMAD, J.-Y.; MESCHY, F. Le bicarbonate de sodium en nutrition porcine. In: CONFÉRENCE GTV/SPACE, 1998, Rennes, France. Procedings... Rennes: 1998.

DOURMAD, J.-Y.; POMAR, C.; MASSE, D. Modélisation du flux de composés à risque pour l'environnement dans un élevage porcin. Journées de la Recherche Porcine, v.34, p.183194, 2002.
EASTER, R.A.; ANDERSON, P.A.; MICHEL, E.J. et al. Response of gestating gilts and starter, grower and finisher swine to biotin, pyridoxine, folacin and thiamine additions to corn-soybean meal diets. Journal of Animal Science, v.28, n.5, p.945954, 1983.

FERRANDO, R.; RUCKEBUSCH, Y.; RERAT, A. Les vitamines. Le porc et son élevage, bases scientifiques et techniques. S.L.: Maloine, 1986. 575p.

GAUDRE, D.; VAUTIER, A. Incidence zootechnique d'un taux de complémentation vitaminique élevé en engraissement. Techniporc, v.29, n.2, p.19-26, 2006.

GAUDRE, D.; LARRERE, V.; GRANIER, R. et al. Quelle réduction du rejet de zinc la 3-phytase microbienne permet-elle chez le porc à partir de $12 \mathrm{~kg}$ de poids vif ? Journées de la Recherche Porcine, v.38, p.5-12, 2006.

GAUDRE, D. Incidence zootechnique d'une augmentation modérée de la complémentation vitaminique de l'aliment distribué entre 12 et $30 \mathrm{~kg}$ de poids vif. Techniporc, v.30, n.1, p.21-28, 2007.

GAUDRE, D.; ALIBERT, L.; QUINIOU, N.; ROYER, E. Recommandations et calcul de l'apport en phosphore digestible par les matières premières et les phytases. Techniporc, v.31, n.5, p.33-39, 2008.

GAUDRE, D.; GRANIER, R. Incidence de la riboflavine sur les performances des porcs en engraissement. Journées de la Recherche Porcine, v.41, p.139-140, 2009.

GRINSTEAD, G.S.; GOODBAND, R.D.; NELSSEN, J.L. et al. Effects of increasing pantothenic acid on growth performance of segregated early-weaned pigs. Swine Day 1998, p.88-90.

HAMILTON, C.R.; VEUM, T.L. Responses of sows and litters to added dietary biotin in environmentally regulated facilities. Journal of Animal Science, v.59, n.1, p.151-157, 1984.

HAMILTON, C.R.; VEUM, T.L. Effect of biotin and (or) lysine additions to corn-soybean meal diets on the performance and nutrient balance of growing pigs. Journal of Animal Science, v.62, p.155-162, 1986.

HARPER, A.F.; LINDEMANN, M.D.; CHIBA, L.I. et al. An assessment of dietary folic acid levels during gestation and lactation on reproductive and lactational performance of sows: a cooperative study. Journal of Animal Science, v.72, p.23382344, 1994.

IFIP-French Institute for pig and pork industry. Vitamines: rôles et besoins dans l'aliment du porc. Paris: IFIP, 2005.

INRA. L'alimentation des animaux monogastriques: porc, lapin, volailles. Paris: INRA, 1984.

INRA-AFZ. Tables de composition et de valeur nutritive des matières premières destinées aux animaux d'élevage. Paris: INRA, 2004.

IVERS, D.J.; VEUM, T.L. Effect of niacin additions to corn-soybean meal diets on performance of pigs from weaning to finishing. Journal of Animal Science, v.71, p.3383-3388, 1993.

JENSEN, M.; HAKKARAINEN, J.; LINDHOLM, A. et al. Vitamin E requirement of growing swine. Journal of Animal Science, v.66, p.3101-3111, 1988 .

JONDREVILLE, C.; PREVY, P.S.; JAFFREZIC, A. et al. Le cuivre dans l'alimentation du porc : oligo-élément essentiel, facteur de croissance et risque potentiel pour l'homme et l'environnement. INRA Productions Animales, v.15, n.4, p.247-265, 2002.

JONDREVILLE, C. Calculer la teneur en P digestible apparent d'un aliment pour porcs à partir des tables INRA-AFZ, Addendum, 2004.

JONGBLOED, A.W.; EVERTS, H.; KEMME, P.A. et al. Quantification of absorbability and requirements of macroelements In: KYRIAZAKIS, I. (Ed.) A quantitative biology of the pig. Wallingford: CAB International, 1999. p.275-298.

KIRCHGESSNER, M.; ROTH-MAIER, D.A.; SPORL, R. Untersuchungen zum Trachtigkeitsanabolismus der spurenelemente Kupfer, Zin, Nickel ung Mangan bei Zuchtsaver. ArchTierernährung, v.31, p.21-34, 1981 
LEWIS, A.J.; CROMWELL, G.L.; PETTIGREW, J.E. Effects of supplemental biotin during gestation and lactation on reproductive performance of sows: a cooperative study. Journal of Animal Science, v.69, p.207-214, 1991.

LINDEMANN, M.D.; KORNEGAY, E.T. Folic acid supplementation to diets of gestating-lactating swine over multiple parities. Journal of Animal Science, v.67, p.459-464, 1989.

LINDEMANN, M.D.; CROMWELL, G.L.; MONEGUE, H.J. Effects of inadequate and high levels of vitamin fortification on performance of weanling pigs. Journal of Animal Science, v.73, suppl.1, p.16, 1995.

LUTZ, T.R.; STAHLY T.S. Dietary riboflavin needs for body maintenance and body protein and fat accretion in pigs. Des Moines: Iowa State University, 1998. p.41-44.

LUTZ, T.R.; STAHLY T.S.; COOK, D.R et al. Effects of dietary thiamin, folacin or niacin regimen on growth in high lean pigs. Journal of Animal Science, v.77, suppl.1, p.189. 1999

MAHAN, D.C. Effects of dietary vitamin E on sow reproductive performance over a five-parity period. Journal of Animal Science, v.72, p.2870-2879, 1994

MAHAN, D.C.; CLINE, T.R.; RICHERT, B. Effects of dietary levels of selenium-enriched yeast and sodium selenite as selenium sources fed to growing-finishing pigs on performance, tissue selenium, serum glutathione peroxidase activity, carcass characteristics and loin quality. Journal of Animal Science, v.77, p.2172-2179, 1999.

MAHAN, D.C.; PETERS, J.C. Lon-term effects of dietary organic and inorganic selenium sources and levels on reproducing sows and their progeny. Journal of Animal Science, v.82, p.13431358,2004

MATTE, J.J.; GIRARD, C.L.; BRISSON, G.J. The role of folic acid in the nutrition of gestating and lactating primiparous sows. Livestock Production Science, v.32, p.131-148, 1992.

NEWCOMB, M.D.; ALLEE, G.L. Water soluble vitamins for weaned pigs. Journal of Animal Science, v.64, suppl.1, p.108, 1986.

NATIONAL RESEARCH COUNCIL - NRC. Nutrient requirement of swine. 10.rev.ed. Washington, D.C.: National Academy Press, 1998.

PEREZ, J.M. L'alimentation minérale des porcins. Techniporc, v.1, n.1, p.1-32, 1978.

POINTILLART, A. La carence expérimentale en vitamine "D" chez le porc. Journées de la Recherche Porcine en France, v.12, p.335-344, 1980.

QUINIOU, N. Le point sur l'équilibre acido-basique chez le porc et le bilan électrolytique des aliments. Techniporc, v.25, n.3, 2002

QUINIOU, N.; CALVAR, C. Est-ce que la truie hyperprolifique valorise un apport en vitamines supérieur aux recommandations ? Techniporc, v.28, n.5, p.3-8, 2005.

REAL, D.E.; NELSSEN, J.L.; UNRUH, J.A. et al. E. Effects of increasing dietary niacin on growth performance and meat quality in finishing pigs reared in two different environments. Journal of Animal Science, v.80, p.3203-3210, 2002.

REVY, P.S.; JONDREVILLE, C.; DOURMAD, et al. Le zinc dans l'alimentation du porc: oligo-élément essentiel et risque potentiel pour l'environnement. INRA Productions Animales, v.16, n.1, p.3-18, 2003.

SIMARD, F.; GUAY, F.; GIRARD, C.L.; et al. La vitamine B12 chez la truie gravide: faut-il en actualiser le besoin ?Journées de la Recherche Porcine, v.36, p.229-234, 2004.

STAHLY, T.S.; WILLIAMS, N.H.; SWENSON, S.G. et al. Dietary B vitamin needs of high and moderate lean growth pigs fed from 9 to $28 \mathrm{~kg}$ body weight. Journal of Animal Science, v.73, suppl.1, p.193, 1995.

STAHLY, T.S.; LUTZ, T.R. Role of pantothenic acid as a modifier of body composition pigs. Journal of Animal Science, v.79, suppl.1, p.68, 2001.

ULLREY, D.E. Vitamin E for swine. Journal of Animal Science, v.53, n.4, p.1039-1056, 1981.

ULLREY, D.E. Basis for regulation of selenium supplements in animal diets. Journal of Animal Science, v.70, p.3922-3927, 1992.

WATKINS, K.L.; SOUTHERN, L.L.; MILLER, J.E. Effect of dietary biotin supplementation on sow reproductive performance and soundness and pig growth and mortality. Journal of Animal Science, v.69, p.201-206, 1991

WILSON, M.E.; PETTIGREW, J.E.; JOHNSTON, L.J. et al. Effect of B vitamin supply upon growth of weanling pigs. Journal of Animal Science, v.70, suppl.1, p.61, 1992a.

WILSON, M.E.; PETTIGREW, J.E.; SHURSON, G.C. et al. Effect of additional $\mathrm{B}$ vitamin in complex diets containing porcine plasma proteins and milk products or in simple diets on growth of weanling pigs. Journal of Animal Science, v.70, suppl.1, p.233, 1992b.

WOODWORTH, J.C.; GOODBAND, R.D.; NELSSEN, J.L. et al. Added dietary pyridoxine, but not thiamine, improves weanling pig growth performance. Journal of Animal Science, v.78, p.88-93, 2000. 